\title{
Pengembangan Keterampilan Kominikatif Antar Siswa Melalui Penerapan Model Pembelajaran Kooperatif Teknik Two Stay Two Stray (TSTS) Dalam Pembelajaran IPS Materi Perpajakan
}

\author{
Elsye Roslina \\ SMP Negeri 1 Cikoneng Kecamatan Cikoneng Kabupaten Ciamis \\ Email : elsye.roslina@gmail.com
}

\begin{abstract}
This research is motivated by concerns about social interaction issues, especially about the weakness of students' communicative skills. Based on first observation in class VIII-A of SMP Negeri 1 Cikoneng, there is a problem about the weakness of communicative skills of students in interacting with other students. To respond this problem, it necessary to prepare learning strategies in IPS lessons. This research is done in SMP Negeri 1 Cikoneng and the subject of this research is the students of class VIII-A. The research method used in this research is classroom action research by applying cooperative learning model of two stay two stray technique in IPS lesson. The instrument used is an observation sheet of students' communicative and cooperative skill assessment, and recorded in field notes. For data collection techniques used observation guides, field notes, and interview guidelines. The learning during the research, first started by determining SK / KD and the preparation of RPP, the second is explained the application of cooperative learning model of two stay two stray technique with communicative skills indicators to be developed, the third shows the communicative skills development of students on cycle 1 first meet to cycle II second meet, the fourth reflects the IPS lesson result by using two stay two stray technique. The conclusion is students' communicative skills experienced significant development in the second cycle of second meet. Suggestions for the next researcher, the researcher hopes the next researcher can resume this research and can develop better methods, in order to achieve maximum results.
\end{abstract}

Keyword : Communicative Skills, Two Stay Two Stray.

Abstrak - Penelitian ini dilatarbelakangi oleh keprihatinan terhadap permasalahan interaksi sosial khususnya mengenai kelemahan keterampilan komunikatif siswa. Berdasarkan observasi awal di kelas VIII-A SMP Negeri 1 Cikoneng, terdapat adanya permasalahan mengenai kelemahan keterampilan komunikatif siswa dalam berinteraksi dengan siswa lain. Untuk menanggapi hal tersebut, diperlukan adanya penyusunan strategi pembelajaran dalam pelajaran IPS. Penelitian ini dilakukan di SMP Negeri 1 Cikoneng sedangkan yang menjadi subjek penelitian adalah siswa kelas VIII-A. Metode penelitian yang digunakan dalam penelitian ini adalah penelitian tindakan kelas dengan menerapkan model pembelajaran kooperatif teknik two stay two stray dalam pelajaran IPS. Instrumen yang digunakan adalah lembar observasi penilaian keterampilan komunikatif dan kooperatif siswa, dan dicatat dalam catatan lapangan. Untuk teknik pengumpulan data digunakan pedoman observasi, catatan lapangan, dan pedoman 
wawancara. Pembelajaran selama penelitian, pertama dimulai dengan menentukan $\mathrm{SK} / \mathrm{KD}$ dan penyusunan RPP, kedua menerangkan penerapan model pembelajaran kooperatif teknik two stay two stray beserta indikator-indikator keterampilan komunikatif yang akan dikembangkan, ketiga menunjukkan adanya perkembangan keterampilan komunikatif siswa pada siklus 1 pertemuan 1 sampai siklus II pertemuan 2, keempat merefleksikan hasil pembelajaran IPS dengan menggunakan teknik two stay two stray. Kesimpulan, keterampilan komunikatif siswa mengalami perkembangan yang signifikan pada siklus II pertemuan 2. Saran bagi peneliti selanjutnya, peneliti berharap peneliti selanjutnya dapat meneruskan kembali penelitian ini dan dapat mengembangkan metode yang lebih baik, agar mencapai hasil yang lebih maksimal.

\section{Kata kunci : Keterampilan Komunikatif, Two Stay Two Stray}

\section{Pendahuluan}

Pembelajaran IPS atau social studies pada umumnya merupakan suatu mata pelajaran yang mengacu pada disiplin-disiplin ilmu sosial yang disederhanakan untuk tujuan pendidikan. Sementara menurut James A. Banks dalam (Sapriya et al, 2008: 3) memberikan definisi bahwa Social Studies adalah bagian dari kurikulum sekolah dasar dan menengah yang mempunyai tanggung jawab pokok membantu para siswa untuk mengembangkan

pengetahuan, keterampilan, sikap dan nilai yang diperlukan dalam hidup bernegara dalam lingkungan masyarakatnya. Dengan melihat definisi tersebut, dapat ditegaskan bahwa tujuan dari pembelajaran IPS itu sendiri adalah untuk memberikan kesempatan kepada para siswa dalam mengembangkan pengetahuan, keterampilan, dan nilai yang memungkinkan mereka dapat menjadi warga negara yang berpartisipasi aktif dalam masyarakat yang demokratis. Jika melihat dari tujuan pembelajaran IPS tersebut, maka dapat dikatakan bahwa antara tujuan pembelajaran IPS dan keterampilan komunikatif ini mempunyai hubungan yang kuat, dimana sebuah perilaku siswa dalam berinteraksi sosial akan dipengaruhi oleh karakter-karakter yang dimiliki oleh siswa itu sendiri. Kemudian, dengan diajarkannya mata pelajaran IPS di sekolah, siswa diharapkan mempunyai keterampilan komunikatif yang baik dan pandai menghadapi perbedaan karakter dengan siswa lain sehingga tercipta hubungan yang harmonis antar siswa.

Berdasarkan observasi awal peneliti di lapangan, pada tanggal 3 Februari 2016 tepatnya di SMPN 1 Cikoneng Kecamatan Cikoneng kelas VIII-A, peneliti menemukan beberapa permasalahan yang terkait dengan kurangnya keterampilan komunikatif terutama yang diakibatkan oleh perbedaan karakter antar siswa. Dalam observasi awal tahun ajaran 2015/2016, peneliti bertindak sebagai guru model pada mata pelajaran IPS yang dibantu oleh guru mitra. Hal ini bertujuan agar peneliti dapat memanfaatkan waktu secara efisien dan lebih leluasa dalam mengamati permasalahan tersebut. Pada pengamatan yang telah dilakukan, terdapat permasalahan yang terjadi baik didalam maupun diluar jam pembelajaran.

Dari hasil pengamatan tersebut, peneliti menemukan bahwa dalam kehidupan di lingkungan sekolah akan terasa lebih majemuk, yaitu dengan ditandainya perbedaan karakter yang mendasar pada setiap kepribadian siswa. Kemudian dari perbedaan karakter yang berhubungan dengan lemahnya keterampilan komunikatif antar siswa dapat dikatakan sebagai salah satu faktor timbulnya masalah. Jadi untuk 
memecahkan masalah ini, diperlukan adanya solusi yang mampu membuat keadaan kelas menjadi kondusif dan terjalin hubungan yang lebih komunikatif/bersahabat antar siswa. Solusi yang dapat diterapkan untuk mencapai tujuan tersebut, peneliti memberi saran untuk menerapkan sebuah metode pembelajaran dalam kelas melalui penerapan model pembelajaran kooperatif (cooperative learning) teknik two stay two stray. Teknik pembelajaran tersebut dapat dijadikan sebagai kunci dalam memecahkan masalah, terutama permasalahan yang berkaitan dengan kurangnya keterampilan komunikatif siswa.

Teknik two stay two stray (TSTS) itu sendiri merupakan salah satu struktur dari model pembelajaran kooperatif yang dikembangkan oleh Spencer Kagan. Struktur dua tinggal dua tamu memberi kesempatan kepada kelompok untuk membagikan hasil dan informasi dengan kelompok lain (Lie, 2008: 61). Proses pembelajaran dengan menggunakan teknik two stay two stray, selain dapat memahami materi yang pelajari, setiap siswa juga berperan aktif dalam menjalin hubungan yang komunikatif / bersahabat untuk berbagi informasi dengan siswa lain, dan diharapkan akan tercipta sebuah pembelajaran yang lebih bermakna dan mampu meningkatkan keterampilan komunikatif pada diri siswa.

Setelah melihat esensi tujuan dari teknik two stay two stray tersebut, peneliti merasa bahwa dengan menerapkan metode pembelajaran ini diharapkan mampu mengatasi masalah yang ada di kelas VIII-A SMPN 1 Cikoneng Kecamatan Cikoneng, yaitu kurangnya keterampilanko munikatif/bersahabat antar siswa. Berangkat dari permasalahan tersebut, peneliti tertarik untuk melakukan sebuah penelitian berupa penelitian tindakan kelas (PTK) dalam rangka "pengembangan keterampilan komunikatif antar siswa melalui penerapan model pembelajaran kooperatif teknik two stay two stray (TSTS) dalam pembelajaran IPS". Dengan harapan melalui penerapan metode pembelajaran kooperatif teknik two stay two stray ini, selain siswa dapat memahami setiap materi yang telah dipelajari, siswa juga diharapkan mampu memperlihatkan rasa senang berbicara, bergaul, saling menghormati dan bekerja sama dengan orang lain, sehingga terjalin interaksi sosial yang menguntungkan antar siswa sesuai dengan tujuan yang ingin dicapai yaitu berkembangnya keterampilan komunikatif antar siswa.

Berdasarkan uraian pada latar belakang masalah, maka rumusan masalah pada penelitian ini adalah sebagai berikut:

1. Bagaimana merencanakan pembelajaran IPS materi perpajakan dengan menggunakan teknik pembelajaran two stay two stray untuk mengembangkan keterampilan komunikatif di kelas VIIIA SMPN 1 Cikoneng Kecamatan Cikoneng Kabupaten Ciamis?

2. Bagaimana mengimplementasikan pembelajaran IPS materi perpajakan dengan menggunakan teknik pembelajaran two stay two stray untuk mengembangkan keterampilan komunikatif di kelas VIII-A SMPN 1 Cikoneng Kecamatan Cikoneng Kabupaten Ciamis?

3. Apakah dengan menggunakan pendekatan model pembelajaran kooperatif teknik two stay two stray (TSTS) dalam pembelajaran IPS materi perpajakan dapat meningkatkan hasil belajar siswa kelas VIII A SMP Negeri 1 Cikoneng Kecamatan Cikoneng Kabupaten Ciamis?

Berdasarkan latar belakang di atas, maka tujuan dari penelitian ini adalah;

1. Untuk mengetahui bagaimana merencanakan pembelajaran IPS materi perpajakan dengan menggunakan teknik pembelajaran two stay two stray untuk 
mengembangkan keterampilan komunikatif di kelas VIII-A SMPN 1 Cikoneng Kecamatan Cikoneng Kabupaten Ciamis.

2. Untuk mengetahui bagaimana mengimplementasikan pembelajaran IPS meteri perpajakan dengan menggunakan teknik pembelajaran two stay two stray untuk mengembangkan keterampilan komunikatif di kelas VIIIA SMPN 1 Cikoneng Kecamatan Cikoneng Kabupaten Ciamis.

3. Untuk mengetahui hasil belajar dalam pembelajaran IPS materi perpajakan setelah menggunakan teknik pembelajaran two stay two stray untuk mengembangkan keterampilan komunikatif di kelas VIII-A SMPN 1 Cikoneng Kecamatan Cikoneng Kabupaten Ciamis.

Hasil penelitian ini diharapkan dapat bermanfaat bagi siswa, guru dan pihak sekolah yang bersangkutan. Secara operasional, manfaat yang ingin dicapai dari penelitian ini adalah sebagai berikut:

1. Bagi Siswa

Hasil penelitian ini diharapkan dapat memberikan manfaat, serta pemahaman bagi siswa untuk mengembangkan keterampilan komunikatif antar siswa.

2. Bagi Guru

Guru dapat merencanakan program pembelajaran khususnya yang dapat meningkatkan karakter komunikatif dan pemahaman siswa dalam pembelajaran IPS yaitu memberikan variasi dalam kegiatan belajar didalam kelas.

3. Bagi Pihak Sekolah

Manfaat yang dapat diberikan untuk pihak sekolah yaitu memberikan gambaran empiris tentang perkembangan keterampilan komunikatif antar siswa melalui pembelajaran IPS.

\section{METODE PENELITIAN}

A. Setting dan Sunjek Penelitian
Lokasi tempat melaksanakan penelitian adalah SMP Negeri 1 Cikoneng Kecamatan Cikoneng Kabupaten Ciamis. Alasan dipilihnya SMP Negeri 1 Cikoneng sebagai lokasi penelitian dikarenakan sekolah tersebut merupakan tempat peneliti mengajar, sehingga dapat memudahkan peneliti dalam melakukan penelitian. Adapun yang menjadi subjek penelitian adalah siswa kelas VIII-A yang berjumlah 34 siswa, yaitu terdiri dari 34 siswa perempuan. Alasan peneliti memilih kelas VIII-A sebagai subjek penelitian, karena dikelas ini ditemukan permasalahan yang sesuai dengan judul PTK peneliti yang harus diperbaiki melalui proses belajar mengajar khususnya dalam mata pelajaran IPS.

Pelaksanaan penelitian ini dilakukan pada bulan Februari 2016 sampai dengan April 2016, sebanyak 2 siklus 4 pertemuan, tahun ajaran 2015/2016. Adapun pelaksanaan penelitian, dimulai dengan tahap persiapan dilanjutkan dengan pelaksanaan tindakan dan diakhiri dengan penyusunan laporan penelitian. Untuk lebih memudahkan pelaksanaan kegiatan maka disusun pelaksanaan sesuai dengan jadwal penelitian. Adapun pelaksanaanya sebagai berikut.

1. Persiapan penelitian 15 s.d 28 Februari 2016

2. Pelaksanaan penelitian

- Siklus I pertemuan 1 dilaksanakan tanggal 2 Maret 2016

- Siklus I pertemuan 2 dilaksanakan tanggal 9 Maret 2016

- Siklus II pertemuan 1 dilaksanakan tanggal 16 Maret 2016

- Siklus II pertemuan 2 dilaksanakan tanggal 23 Maret 2016

3. Pengolahan dan penggandaan hasil penelitian 24 Maret s.d 7 April 2016

4. Seminar hasil penelitian 16 April 2016

5. Pelaporan hasil penelitian 21 April 2016

\section{B. Setting dan Sunjek Penelitian}


Prosedur penelitian terdiri dari Pendeskripsian data dilakukan agar data perencanaan, pelaksanaan tindakan, yang telah terseleksi menjadi bermakna, observasi, dan refleksi.

\section{Teknik Pengumpulan Data}

Secara garis besar teknik pengumpulan data dalam penelitian ini tercantum dalam tabel berikut:

TABEL 1

SUMBER DATA, JENIS DATA, DAN INSTRUMEN

\begin{tabular}{|c|c|c|c|}
\hline No. & Sumber & Jenis Data & Instrumen \\
\hline 1. & Siswa & $\begin{array}{l}\text { Keterampila } \\
\mathrm{n} \\
\text { komunikatif } \\
\text { siswa dalam }\end{array}$ & $\begin{array}{c}\text { Pedoman } \\
\text { Observasi }\end{array}$ \\
\hline 2. & Siswa & $\begin{array}{l}\text { Tanggapan } \\
\text { siswa } \\
\text { terhadap } \\
\text { pembelajara } \\
\text { n IPS dengan } \\
\text { model }\end{array}$ & $\begin{array}{c}\text { Wawancar } \\
\text { Pedoman }\end{array}$ \\
\hline 3. & $\begin{array}{c}\text { Observe } \\
\mathrm{r}\end{array}$ & $\begin{array}{l}\text { Aktifitas } \\
\text { guru dan } \\
\text { siswa selama }\end{array}$ & $\begin{array}{c}\text { Catatan } \\
\text { Lapanga } \\
\mathrm{n}\end{array}$ \\
\hline 4. & Tes & Tes Hasil & Soal Tes \\
\hline
\end{tabular}

\section{Teknik Analisis Data}

Menganalisis data merupakan proses mengolah dan menginterpretasikan data dengan tujuan untuk mendudukkan berbagai informasi sesuai dengan fungsinya hingga memiliki makna dan arti yang jelas sesuai dengan tujuan penelitian. Analisis data yang akan dilakukan melalui tiga tahap (Sanjaya, 2011: 106), diantaranya:

\section{a. Reduksi Data}

Reduksi data dilakukan dengan menyeleksi data yang sesuai dengan fokus permasalahan. Dalam kegiatan ini peneliti mengumpulkan semua instrumen yang digunakan untuk mengumpulkan data kemudian dikelompokkan berdasarkan fokus masalah.

b. Mendeskripsikan Data pendeskripsian dilakukan dalam bentuk naratif, grafik maupun tabel. Membuat Kesimpulan Berdasarkan Deskripsi Data.

\section{E. Indikator Keberhasilan}

Tolak ukur atau kriteria keberhasilan penelitian ini dapat dilihat dari dua sisi, yaitu dari sisi proses dan dari sisi hasil.

TABEL 2

KRITERIA PENILAIAN PENGUASAAN MATERI

\begin{tabular}{|c|c|c|}
\hline No & NiIai & Kriteria \\
\hline 1 & $<60$ & Rendah \\
\hline 2 & $61-75$ & Cukup \\
\hline 3 & $76-90$ & Tinggi \\
\hline 4 & $91-100$ & Tinggi Sekali \\
\hline
\end{tabular}

TABEL 3

KRITERIA KETUNTASAN BELAJAR SISWA

\begin{tabular}{|c|c|c|}
\hline No & NiIai & Kriteria \\
\hline 1 & $<65$ & $\begin{array}{c}\text { Tidak Tuntas } \\
\text { (Remidi) }\end{array}$ \\
\hline 2 & $65-90$ & Tuntas \\
\hline 3 & $91-100$ & Pengayaan \\
\hline
\end{tabular}

\section{HASIL PENELITIAN DAN PEMBAHASAN}

\section{A. Data Hasil Catatan Lapangan}

Berdasarkan hasil catatan lapangan yang telah peneliti buat, dapat dideskripsikan mengenai kegiatan guru dan siswa dari tiap siklus yang telah dilakukan selama proses pembelajaran di kelas. Dari catatan lapangan ini, dapat dilihat bahwa kegiatan guru pada siklus I pertemuan 1 masih kurang tegas dalam mengatur siswa-siswa yang tidak disiplin, karena ketika pembelajaran akan segera dimulai beberapa siswa masih berada diluar kelas. Selain itu, guru juga kurang jelas dalam memberitahukan kepada siswa tentang tata cara pembelajaran kooperatif 
teknik two stay two stray, sehingga siswa merasa bingung dalam memahami tugas yang harus mereka kerjakan.

Pada pelaksanaan siklus I pertemuan 2, masih ada beberapa siswa yang terlambat memasuki kelas, dan guru masih kurang tegas dalam mengatur siswa-siswa yang belum disiplin ketika pembelajaran akan segera dimulai. Sebelum pembelajaran dimulai guru selalu mengingatkan akan ketercapaian yang diharapkan yaitu peningkatan keterampilan komunikatif pada diri siswa. Dalam pelaksanaan siklus I pertemuan 2 ini, beberapa siswa sudah memahami indikator dari keterampilan komunikatif, dimana semua siswa sudah mampu menerima anggota kelompok lainnya dan tidak ada siswa yang mengeluh akan penentuan anggota kelompok. Sedangkan kekurangan yang terdapat pada siklus I pertemuan 2 ini, siswa belum mampu menerapkan indikator lain secara maksimal.

Pada pelaksanaan siklus II pertemuan 1, guru datang terlambat dan beberapa siswa ada yang masih diluar kelas atau pergi ke kantin untuk membeli makanan kecil atau permen. Rupanya beberapa siswa tersebut berinisiatif untuk memberikan suguhan berupa permen kepada siswa yang berkunjung ke kelompoknya. Menanggapi hal ini, guru memberikan dukungan penuh kepada siswa yang mempunyai tindakan positif tersebut. Dalam penerapannya sendiri, semua siswa terlihat lebih antusias dan semangat dari pada tindakan sebelumnya, dimana pada pelaksanaan siklus ini, terdapat tindakan inisiatif dari siswa yang menggambarkan sikap saling menghormati antar siswa. Selain itu, hubungan kerjasama siswa terlihat lebih bersahabat, baik kerjasama antar anggota kelompok maupun kerjasama antar kelompok. Dalam hal ini, siswa yang bertugas sebagai tamu sudah mampu mendengarkan penjelasan materi tanpa banyak bergurau dan dapat melaporkan hasil kerjanya dengan baik. Sedangkan, siswa yang bertugas sebagai penerima tamupun sudah dapat menjelaskan materi secara komunikatif kepada tamunya.

Pada pelaksanaan siklus II pertemuan 2, diawal pembelajaran terlihat beberapa siswa yang merasa jenuh dengan penerapan pembelajaran kooperatif teknik two stay two stray. Mereka menganggap bahwa metode ini sudah terlalu sering dilakukan oleh guru, sehingga dalam pelaksanaanya, kerjasama antar siswa berjalan dengan kurang maksimal. Selain itu, konsentrasi siswa dalam pelajaran juga mulai berkurang terutama diakhir jam pelajaran. Dalam hal ini dapat disimpulkan bahwa keterampilan komuniktif siswa pada siklus II pertemuan 2 cenderung menurun dari pada pelaksanaan siklus sebelumnya.

Jika dilihat secara keseluruhan, maka dapat disimpulkan bahwa dari pelaksanaan siklus I pertemuan 1 sampai siklus II pertemuan 2, keterampilan komunikatif siswa mengalami peningkatan yang terjadi secara bertahap.

\section{B. Data Hasil Wawancara}

Kegiatan wawancara dilakukan pada saat kegiatan penelitian telah selesai. Dalam kegiatan ini, peneliti mewawancarai beberapa siswa dari kelas VIII-A yang menjadi responden. Siswa yang dipilih sebagai responden berjumlah 9 siswa, dan pemilihan responden dilakukan secara acak atau berdasarkan keragaman keterampilan komunikatif yang dimiliki oleh siswa. Pertanyaan dalam wawancara ini sendiri menyangkut penerapan pembelajaran kooperatfi teknik TSTS untuk meningkatkan keterampilan komunikatif dalam pelajaran IPS. Pertanyaan tersebut antara lain :

1. Bagaimana pendapat anda terhadap pembelajaran IPS selama ini?

2. Apakah anda sebelumnya pernah mengikuti pembelajaran IPS dengan menggunakan model cooperative learning teknik two stay two stray?

3. Bagaimana tanggapan anda terhadap 
pembelajaran IPS dengan menggunakan model cooperative learning teknik two stay two stray?

4. Apakah anda mengalami kesulitan dalam mengikuti pembelajaran dengan model cooperative learning teknik two stay two stray?

5. Apakah pembelajaran IPS dengan model cooperative learning teknik two stay two stray dapat meningkatkan keterampilan komunikatif anda?

Adapun hasil wawancara yang telah dilakukan kepada responden yaitu:

1. Pertanyaan nomor 1

Berdasarkan hasil wawancara mengenai pendapat siswa terhadap pembelajaran IPS sebelumnya, dapat dikatakan bahwa sebagian besar siswa menjawab pelajaran IPS itu menegangkan dan membosankan, karena gurunya yang terbilang terlalu tegas dalam menerangkan materi pelajaran, sehingga siswa merasa kesulitan dalam menangkap materi yang dijelaskan oleh guru.

2. Pertanyaan nomor 2

Berdasarkan pertanyaan nomor 2, sebagian besar siswa menjawab belum pernah mengikuti pelajaran IPS dengan menggunakan model cooperative learning teknik two stay two stray, karena guru IPS sebelumnya hanya menerapkan metode diskusi yang sebatas belajar kelompok kemudian hasil kerja kelompoknya dipresentasikan di depan kelas, sehingga keterampilan siswa untuk bersosialisasi terutama untuk mengembangkan keterampilan komunikatif dalam pembelajaran IPS kurang diperhatikan oleh guru.

3. Pertanyaan nomor 3

Berdasarkan hasil wawancara mengenai tanggapan siswa terhadap pelajaran IPS dengan menggunakan model cooperative learning teknik two stay two stray, sebagian besar siswa menganggap bahwa metode ini menarik dan menyenangkan, karena mereka belum pernah mengikuti metode pembelajaran ini pada proses pembelajaran sebelumnya. Dalam hal ini, siswa merasa lebih diberikan kesempatan untuk menjalin kerjasama dengan siswa lain dan dapat memahami perbedaan karakter antar siswa.

4. Pertanyaan nomor 4

Berdasarkan pertanyaan nomor 4, sebagian besar siswa merasa kesulitan dalam mengikuti pembelajaran kooperatif ini, karena kendala awalnya terletak pada perbedaan karakter dan keterampilan komunikatif yang dimiliki oleh masingmasing siswa, sehingga membuat mereka cukup kesulitan dalam menjalin kerjasama dengan siswa lainnya.

5. Pertanyaan nomor 5

Berdasarkan pertanyaan nomor 5, sebagian besar siswa menjawab bahwa melalui pembelajaran kooperatif ini dapat meningkatkan keterampilan komunikatif siswa dan sangat penting untuk diterapkan dalam pelajaran IPS. Dalam hal ini siswa merasa lebih mempunyai tanggung jawab perseorangan, dapat menjalin kerjasama yang baik antar siswa, mampu meningkatkan toleransi atau menghargai perbedaan karakter tiap siswa, dan mempererat hubungan persahabatan, serta melatih siswa dalam berkomunikasi dengan baik.

\section{Data Hasil Pedoman Observasi Keterampilan Komunikatif Siswa}

Data ini diperoleh dengan melakukan observasi yang dilaksanakan pada setiap siklusnya. Adapun indikator-indikator yang terdapat dalam keterampilan komunikatif yang telah disusun adalah sebagai berikut: a). Rasa senang berbicara dan bekerjasama antar siswa, b). Berkomunikasi dengan bahasa yang santun, c). Berperilaku sopan, d) Saling menghargai antar siswa, e). Mendengarkan penjelasan dari siswa lain dengan baik, dan f). Terjalin hubungan yang harmonis antar siswa. Data yang diperoleh dari observasi ini, kemudian dikonversi kedalam rentan skor menggunakan skala interval dan dikonversikan ke dalam bentuk 
nilai, yaitu: kurang, cukup, baik. Berikut ini, merupakan rincian skor dari observasi yang telah dilaksanakan:

TABEL 4

PRESENTASE PERKEMBANGAN KETERAMPILAN KOMUNIKATIF SISWA

\begin{tabular}{|c|r|c|c|c|c|}
\hline $\begin{array}{c}\text { N } \\
\text { o }\end{array}$ & $\begin{array}{r}\text { Nama } \\
\text { Kelomp }\end{array}$ & $\begin{array}{c}\text { Siklu } \\
\text { s 1 P1 }\end{array}$ & $\begin{array}{c}\text { Siklu } \\
\text { s I P2 }\end{array}$ & $\begin{array}{c}\text { Siklus } \\
\text { II P1 }\end{array}$ & $\begin{array}{c}\text { Siklu } \\
\text { S II }\end{array}$ \\
\hline 1 & Kelompok & 8 & 11 & 14 & 15 \\
\hline 2 & Kelompok & 8 & 13 & 15 & 16 \\
\hline 3 & Kelompok & 8 & 11 & 14 & 15 \\
\hline 4 & Kelompok & 9 & 13 & 17 & 17 \\
\hline 5 & Kelompok & 6 & 9 & 15 & 16 \\
\hline 6 & Kelompok & 9 & 13 & 16 & 17 \\
\hline 7 & Kelompok & 8 & 11 & 16 & 17 \\
\hline Jumlah Skor & $\mathbf{5 6}$ & $\mathbf{8 1}$ & $\mathbf{1 0 7}$ & $\mathbf{1 1 3}$ \\
\hline Jumlah Skor & $\mathbf{1 4 4}$ & $\mathbf{1 4 4}$ & $\mathbf{1 4 4}$ & $\mathbf{1 4 4}$ \\
\hline \multicolumn{7}{|c|}{ Rata- Rata } & $\mathbf{3 8 , 8 9}$ & $\mathbf{5 6 , 2 5}$ & $\mathbf{7 4 , 3 1}$ & $\mathbf{7 8 , 4 7}$ \\
\hline \\
Perhitungan rata-rata (persentase):Jumlah \\
Skor Kelompok x 100\% \\
\hline
\end{tabular}

Jumlah Skor Maksimal

KONVERSI RATA-RATA (PRESENTASE)

\begin{tabular}{|c|c|}
\hline Nilai & Skor Presentase \\
\hline Kurang & $0-33,3 \%$ \\
\hline Cukup & $33,4 \%-66,6 \%$ \\
\hline Baik & $66,7 \%-100 \%$ \\
\hline
\end{tabular}

Berdasarkan hasil dari tabel 4 dapat dilihat perkembangan keterampilan komunikatif siswa dari hasil perolehan skor pada setiap pelaksanaan siklusnya. Perubahan tersebut terjadi cukup signifikan, dimana setiap anggota kelompok mampu mengembangkan keterampilan komunikatifnya selama penerapan pembelajaran kooperatif. Berikut diagram skor yang didapatkan setiap kelompok dalam mengembangkan keterampilan komunikatif melalui penerapan pembelajaran kooperatif teknik two stay two stray:

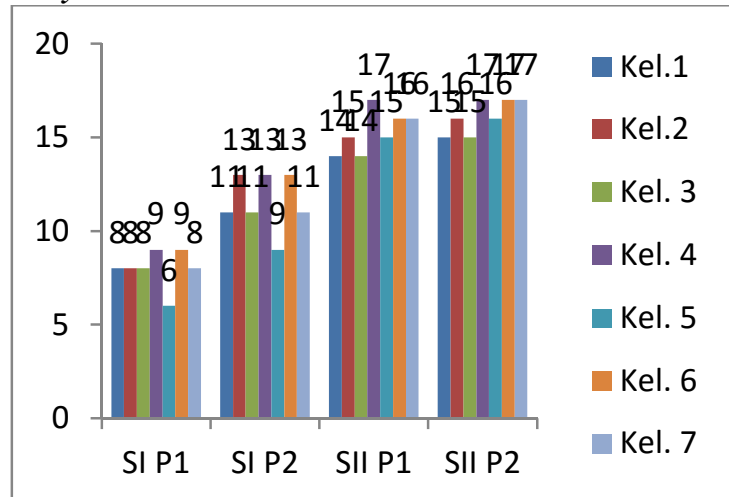

Gambar 1. Diagram Skor Perkembangan Keterampilan Komunikatif Siswa

Dari data diatas dapat diketahui bahwa keterampilan komunikatif siswa melalui pembelajaran kooperatif teknik TSTS mengalami sebuah peningkatan secara bertahap. Berdasarkan pada siklus 1 pertemuan 1 rata-rata presentase yang didapatkan adalah $38,89 \%$, dengan kata lain pada siklus I pertemuan 1 keterampilan komunikatif siswa mencapai kategori cukup. Kemudian pada siklus I pertemuan 2, keterampilan komunikatif siswa mengalami perkembangan dengan presentase $56,25 \%$ dengan mencapai kategori cukup. Pada siklus II pertemuan 1, keterampilan komunikatif siswa terus mengalami perkembangan dengan mencapai presentase $74,31 \%$, dengan kategori baik. Sedangkan pada siklus II pertemuan 2, keterampilan komunikatif siswa meningkat dari siklus sebelumnya yaitu dengan mencapai presentase $78,47 \%$ dengan pencapaian kategori baik.

Berdasarkan presentase tersebut, agar lebih terlihat perubahan keterampilan komunikatif siswa melalui pembelajaran kooperatif teknik TSTS dapat digambarkan pada diagram di bawah ini: 


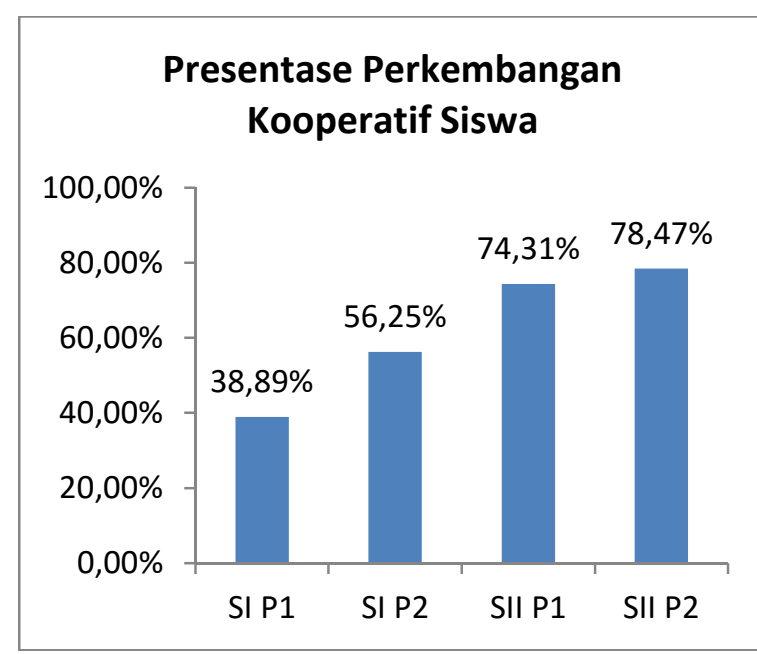

Gambar 2. Diagram Presentase

Peningkatan Keterampilan Komunikatif Siswa

\section{Data Hasil Pedoman Observasi Kooperatif Siswa}

Adapun indikator keterampilan komunikatif berdasarkan unsur kooperatif siswa dalam penelitian ini, antara lain : a).Saling ketergantungan positif antar anggota kelompok, b). Interaksi tatap muka secara langsung, c). Tanggung jawab perseorangan, dan d). Komunikasi antar anggota kelompok. Data yang diperoleh berdasarkan unsur kooperatif ini kemudian dikonversi kedalam rentan skor menggunakan skala interval dan dikonversikan ke dalam bentuk nilai, yaitu: kurang, cukup, baik. Berikut rincian skor dari observasi yang telah dilaksanakan: TABEL 5

PRESENTASE PERKEMBANGAN KOOPERATIF SISWA

\begin{tabular}{|c|c|c|c|c|c|}
\hline No & $\begin{array}{r}\text { Nama } \\
\text { Kolom }\end{array}$ & $\begin{array}{c}\text { Siklu } \\
\text { I P1 } 1\end{array}$ & $\begin{array}{c}\text { Siklu } \\
\text { I P }\end{array}$ & $\begin{array}{c}\text { Siklus } \\
\text { I P1 }\end{array}$ & $\begin{array}{c}\text { Siklu } \\
\text { IU }\end{array}$ \\
\hline 1 & Kelompo & 5 & 7 & 10 & 11 \\
\hline 2 & Kelompo & 6 & 9 & 11 & 12 \\
\hline 3 & Kelompo & 5 & 7 & 10 & 11 \\
\hline 4 & Kelompo & 7 & 10 & 12 & 12 \\
\hline 5 & Kelompo & 5 & 7 & 10 & 11 \\
\hline 6 & Kelompo & 6 & 9 & 11 & 12 \\
\hline 7 & Kelompo & 5 & 7 & 10 & 11 \\
\hline $\begin{array}{c}\text { Jumlah Skor } \\
\text { Kelompok }\end{array}$ & $\mathbf{3 9}$ & $\mathbf{5 6}$ & $\mathbf{7 4}$ & $\mathbf{8 9}$ \\
\hline
\end{tabular}

\begin{tabular}{|c|c|c|c|c|}
\hline $\begin{array}{c}\text { Jumlah Skor } \\
\text { Mal_imal }\end{array}$ & 120 & 120 & 120 & 120 \\
\hline Rata- Rata & $\mathbf{3 2 , 5 0}$ & $\mathbf{4 6 , 6 7}$ & $\mathbf{6 1 , 6 7}$ & $\mathbf{7 4 , 1 7}$ \\
\hline
\end{tabular}

Perhitungan rata-rata (persentase):Jumlah Skor Kelompok x 100\%

Jumlah $\quad$ Skor
Maksimal

\section{KONVERSI RATA-RATA (PRESENTASE)}

\begin{tabular}{|c|c|}
\hline Nilai & Skor Presentase \\
\hline Kurang & $0-33,3 \%$ \\
\hline Cukup & $33,4 \%-66,6 \%$ \\
\hline Baik & $66,7 \%-100 \%$ \\
\hline
\end{tabular}

Berdasarkan hasil dari tabel 5 dapat dilihat perkembangan keterampilan komunikatif siswa berdasarkan unsur kooperatif dari setiap pelaksanaan siklusnya. Dari hasil perolehan skor masingmasing kelompok terlihat mengalami sebuah perkembangan yang signifikan, namun pada siklus II pertemuan 2 mengalami sebuah penurunan.

Berikut diagram skor yang didapatkan setiap kelompok dalam pengembangan keterampilan komunikatif siswa berdasarkan unsur kooperatif melalui pembelajaran teknik two stay two stray:

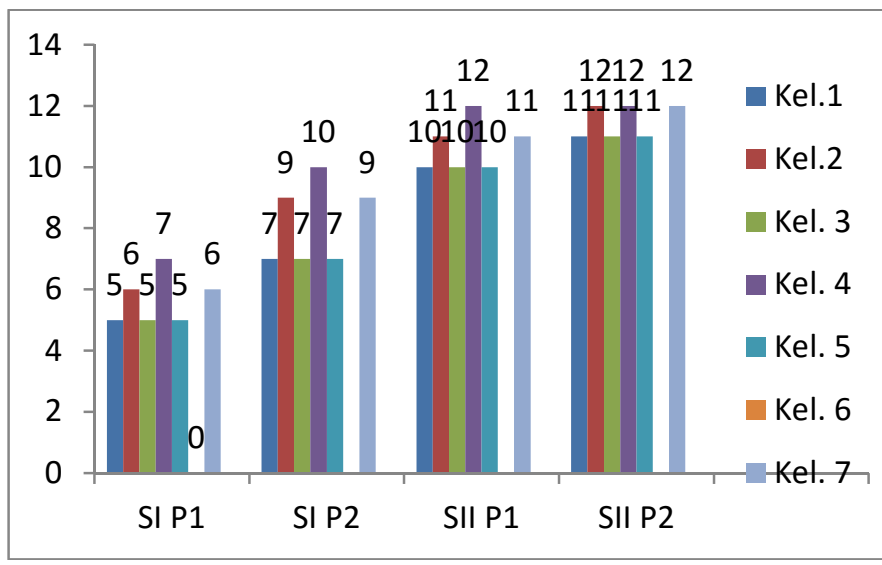

Gambar 3. Diagram Skor Perkembangan Kooperatif Siswa

Dilihat dari unsur kooperatif, dapat diketahui bahwa keterampilan komunikatif siswa melalui teknik TSTS mengalami sebuah peningkatan yang terjadi secara bertahap. Pada siklus I pertemuan 1 rata- 
rata presentase yang didapatkan mencapai $32,50 \%$, dan termasuk ke dalam kategori kurang. Pada siklus I pertemuan 2, rata-rata presentase yang didapatkan mampu mencapai 46,67\%, dengan kategori cukup. Kemudian pada siklus II pertemuan 2, kooperatif siswa terus mengalami peningkatan dengan mencapai presentase $61,67 \%$, dengan kategori cukup. Pada siklus II pertemuan 2, mengalami peningkatan dengan mencapai presentase $74,17 \%$ dengan kategori baik.

Berdasarkan presentase tersebut, agar lebih terlihat jelas mengenai perubahan kooperatif siswa melalui teknik TSTS dalam pembelajaran IPS, dapat digambarkanpadadiagramdibawah ini:

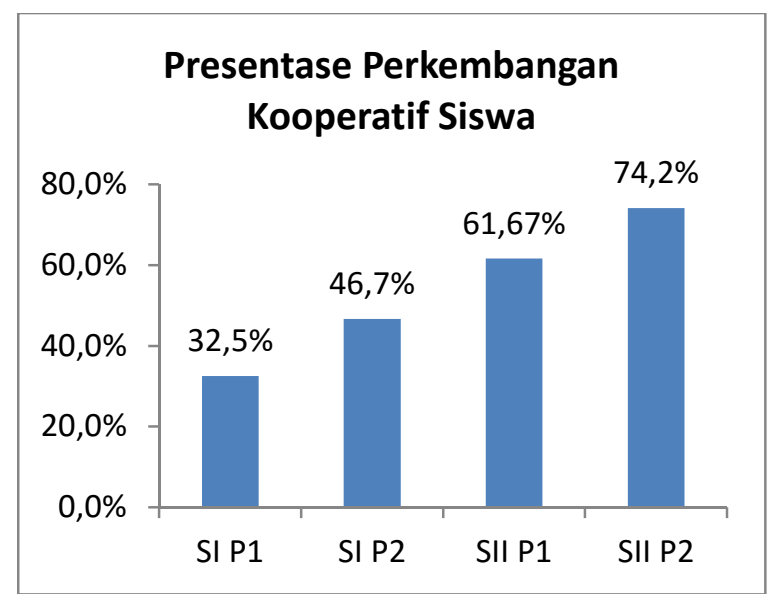

Gambar 4. Diagram Presentase Peningkatan Kooperatif Siswa

Dilihat dari data yang didapatkan selama penelitian, dapat dikatakan bahwa keterampilan komunikatif siswa kelas VIIIA SMPN 1 Cikoneng Kecamatan Cikoneng dapat meningkat melalui penerapan pembelajaran kooperatif teknik TSTS. Peningkatan ini dimulai dari pelaksanaan siklus kesatu sampai siklus II pertemuan 1 .

Pada siklus I pertemuan 1, siswa memang terlihat antusias terhadap teknik pembelajaran yang digunakan, karena ini merupakan hal baru bagi siswa dan belum pernah diterapkan oleh siswa dalam kegiatan pembelajaran sebelumnya. Namun, diawal penerapan teknik pembelajaran tersebut, siswa mengalami kesulitan untuk menjalin kerjasama yang efektif, dikarenakan terdapat perbedaan karakter yang dimiliki antar siswa.

Pada siklus I pertemuan 2, perkembangan keterampilan komunikatif siswa melalui pembelajaran kooperatif teknik TSTS mengalami peningkatan, hal ini dapat dilihat ketika siswa mampu saling menghargai dan menjalin kerjasama yang lebih baik antar anggota kelompoknya, dimana semua siswa sudah mampu menerima terhadap penentuan anggota kelompok yang sebelumnya menjadi permasalahan bagi guru.

Pada sikus II pertemuan 1, keterampilan komunikatif/bersahabat antar siswa mengalami peningkatan yang lebih baik dari pada siklus sebelumnya, dimana kerjasama antar anggota kelompok maupun dengan kelompok lain sudah terjalin dengan baik. Bahkan pada siklus II pertemuan 1 ini, terdapat tindakan inisiatif para siswa untuk saling menghormati antar siswa, yaitu dengan menyediakan suguhan untuk para siswa (tamu) yang akan berkunjung ke kelompoknya, sehingga siswa terlihat lebih senang selama mengikuti proses pembelajaran.

Sedangkan pada siklus II pertemuan 2, keterampilan komunikatif siswa terlihat meningkat. Pada awal pembelajaran siswa terlihat antusias dan ditengah pembelajaran berlangsung siswa tidak terlihat jenuh. Jadi dapat disimpulkan bahwa pelaksanaan siklus II pertemuan 2 berjalan efektif, dan keterampilan komuniktif siswa cenderung meningkat dari pada siklus sebelumnya.

\section{E. Analisis Hasil Penelitian}

Berdasarkan hasil temuan di lapangan selama penelitian berlangsung, dapat diketahui bahwa pembelajaran kooperatif teknik two stay two stray dapat dijadikan sebagai alternatif yang digunakan untuk meningkatkan keterampilan komunikatif/bersahabat antar siswa. Berdasarkan penelitian yang telah 
dilaksanakan bahwa keterampilan komunikatif siswa kelas VIII-A mengalami perkembangan yang signifikan. Hal tersebut dapatdilihatpadaanalisis sebagaiberikut:

1) Bagaimana

merencanakan pembelajaran IPS dengan menggunakan teknik pembelajaran two stay two stray untuk mengembangkan keterampilan komunikatif di kelas VIII-A SMPN 1 Cikoneng Kecamatan Cikoneng?: Sebelum melakukan penelitian, peneliti melakukan perencanaan dalam menerapkan teknik pembelajaran two stay two stray dalam pembelajaran IPS. Perencanaan ini dilakukan melalui diskusi dengan guru mitra sebagai upaya menyusun langkah yang tepat, serta disesuaikan dengan latar belakang masalah yang terdapat dalam kelas VIIIA SMPN 1 Cikoneng Kecamatan Cikoneng. Dalam diskusi yang peneliti lakukan bersama guru mitra, hal yang pertama dibahas yaitu mengenai jadwal pelaksanaan penelitian dalam kelas VIII-A. Hal ini dilakukan untuk mendapatkan izin serta meminta bantuan kepada guru mitra untuk bersedia menjadi observer. Selanjutnya, peneliti mendiskusikan tentang rencana pembelajaran dan penilaian yang akan digunakan dalam penelitian. Sedangkan penentuan materi yang akan diajarkan melalui teknik two stay two stray dapat mengikuti materi yang sedang berlangsung, sehingga peneliti tidak merasa kesulitan untuk menentukan materi pelajaran, karena inti dalam penelitian ini adalah untuk mengembangkan keterampilan komunikatif/bersahabat melalui kerjasama antar siswa. Materi yang akan digunakan dalam pelaksanaan penelitian, yaitu dengan menentukan Standar Kompetensi tentang "memahami kegiatan perekonomian Indonesia". Berdasarkan materi tersebut, selanjutnya peneliti menyusun RPP yang tepat dan disesuaikan dengan materi yang akan diajarkan, hal ini dilakukan agar peneliti mempunyai batasan dan rencana yang tepat selama melaksanakan pembelajaran di kelas. Dalam menentukan model pembelajaran kooperatif teknik two stay two stray, disesuaikan untuk mengatasi permasalahan perbedaan karakter siswa yang ada dalam kelas VIII-A, tepatnya mengenai kelemahan keterampilan komunikatif siswa. Selain itu, penentuan model pembelajaran ini tidak terlepas dari tujuan yang terdapat dalam pembelajaran kooperatif. Pengelompokkan siswa dalam pembelajaran kooperatif ini, dilakukan dengan memandang perbedaan karakter siswa atau dilakukan secara heterogen. Dengan alasan, melalui pembagian kelompok secara heterogen akan menjadikan siswa lebih aktif, karena diberikan kesempatan untuk saling mengajar dan saling mendukung. Selain itu, siswa dapat saling menghargai segala perbedaan latar belakang yang dimiliki oleh siswa lainnya.

2) Bagaimana mengimplementasikan pembelajaran IPS dengan menggunakan teknik pembelajaran two stay two stray untuk mengembangkan keterampilan komunikatif di kelas VIII-A SMPN 1 Cikoneng Kecamatan Cikoneng?: Sebelum pelaksanaan tindakan dilakukan, guru memulai proses pembelajaran dengan menjelaskan tentang teknik two stay two stray berserta tata caranya kepada siswa. Selain itu, guru memberikan stimulus kepada siswa mengenai pentingnya keterampilan komunikatif/bersahabat, serta menyampaikan beberapa indikatorindikator keterampilan komunikatif yang akan dikembangkan melalui pembelajaran kooperatif. Hal ini dilakukan agar siswa lebih memahami tentang penerapan teknik pembelajaran TSTS dan termotivasi untuk mengambangkan keterampilan komunikatifnya. Proses selanjutnya, guru membagi seluruh siswa menjadi beberapa kelompok yang dilakukan secara heterogen. Pada dasarnya, teknik two stay two stray merupakan teknik yang 
menuntut siswa untuk bekerja lebih aktif dalam menjalin kerjasama dan menyampaikan materi kepada siswa lain, sedangkan guru lebih berperan sebagai pembimbing jalannya proses pembelajaran. Jadi, dalam proses penyampaian materi pelajaran, guru hanya menjelaskan materi selama beberapa menit, selanjutnya materi tersebut dibagikan menjadi beberapa bagian untuk dibagikan kepada tiap-tiap kelompok. Sebelum penerapan teknik two stay two stray dilakukan, guru memberikan kesempatan kepada setiap kelompok untuk mendiskusikan peran siswa sebagai tamu maupun penerima tamu, dan guru menyiapkan LKS yang akan dibagikan kepada setiap kelompok untuk merangkum materi pelajaran serta sebagai bukti bahwa setiap kelompok telah menjalankan tugas-tugasnya. Sedangkan saat proses pembelajaran berlangsung, guru hanya memantau dan melakukan intervensi jika terjadi masalah dalam menjalankan kerjasama antar anggota kelompok. Selain pemantauan yang dilakukan oleh guru, selama proses TSTS ini berlangsung, keterampilan komunikatif juga diamati dan dinilai oleh observer. Ketika setiap kelompok telah menjalankan tugasnya, yaitu berkunjung dan menerima tamu dari seluruh kelompok yang ada, tugas selanjutnya adalah melaporkan hasil dalam lembar LKS yang berisi tentang rangkuman materi. Diakhir pembelajaran, guru membuka sesi tanya jawab kepada siswa yang kurang memahami materi dan meluruskan kesalahpahaman selama mengikuti pembelajaran. Selain itu, guru mengingatkan kepada siswa agar mereka dapat mengembangkan keterampilan komunikatifnya dengan selalu memperhatikan indikator-indikator yang menjadi kompetensi dalam proses penilaian.

3) Bagaimana merefleksikan hasil pembelajaran IPS dengan menggunakan teknik pembelajaran two stay two stray untuk mengembangkan keterampilan komunikatif di kelas VIII-A SMPN 1 Cikoneng Kecamatan Cikoneng?: Hasil yang didapatkan dari penerapan teknik two stay two stray dalam pembelajaran IPS, menyatakan bahwa keterampilan komunikatif/bersahabat siswa kelas VIIIA SMPN 1 Cikoneng Kecamatan Cikoneng mengalami peningkatan dari pelaksanaan tiap siklusnya. Peningkatan ini berjalan secara bertahap, dimana pada siklus I pertemuan 1 masih banyak siswa yang kesulitan dalam bekerjasama karena perbedaan karakter antar siswa yang sulit disatukan, sehingga kerjasama antar anggota kelompok berjalan kurang efektif. Pada siklus I pertemuan 2, siswa sudah dapat menjalankan kerjasama antar anggota kelompoknya namun, untuk bekerjasama dengan kelompok lain masih diselingi dengan guraun atau kurang serius dalam menjalankan tugasnya. Pada siklus II pertemuan 1, keterampilan komunikatif siswa mengalami peningkatan yang cukup signifikan, karena mereka dapat memperbaiki kesalahan- kesalahan sebelumnya. Dalam hal ini, siswa mampu menjalin kerjasama yang lebih bersahabat, baik kerjasama yang dilakukan antar anggota kelompok maupun dengan kelompok yang lain. Dalam merefleksikan hasil dari setiap siklus, peneliti selalu mendiskusikannya dengan guru mitra untuk mendapatkan gambaran mengenai perkembangan keterampilan komunikatif siswa, serta merundingkan rencana perbaikan yang diperlukan untuk mengatasi kekurangan yang masih ada. Adapun inti dalam kegiatan revisi untuk mencapai tujuan penelitian, yaitu dengan selalu memberikan motivasi pada setiap kegiatan pelaksanaan. Dalam hal ini, stimulus diberikan kepada siswa berupa nilai-nilai yang terkandung dalam pembelajaran kooperatif, serta mengingatkan kembali mengenai indikator-indikator keterampilan komunikatif yang harus dikembangkan 
oleh siswa. Dengan demikian, siswa akan menyadari bahwa apa yang mereka kerjakan bukan sekedar menyelesaiakan tugasnya, namun mereka dapat mengembangkan keterampilan komunikatif dengan penuh kesadaran.

\section{KESIMPULAN DAN SARAN}

Pengembangkan keterampilan komunikatif siswa kelas VIII-A SMPN 1 Cikoneng Kecamatan Cikoneng melalui pembelajaran kooperatif tehknik two stay two stray dalam pembelajaran IPS, dapat disimpulkan sebagai berikut:

Pertama, perencanaan dalam mengembangkan keterampilan komunikatif siswa melalui pembelajaran kooperatif teknik TSTS dalam pembelajaran IPS dilakukan melalui diskusi yang melibatkan antara peneliti dan guru mitra. Pada tahap perencanaan, peneliti dan guru mitra menyusun perangkat pembelajaran yaitu silabus, RPP dan LKS. Selain itu, perencanaan juga mencakup alat pengumpulan data yang digunakan selama penelitian, berupa pedoman observasi, rubrik, catatan lapangan, dan pedoman wawancara. Dalam proses pembelajaran, materi yang disampaikan oleh guru ditentukan dengan SK/KD yang sedang berlangsung. Sedangkan dalam penentuan anggota kelompok, dilakukan secara heterogen berdasarkan perbedaan karakter siswa, gender, dan prestasi akademik. Dengan demikian, perencanaan yang telah dilakukan tidak hanya sesuai dengan kurikulum yang berlaku, tetapi sesuai pula dengan situasi dan kondisi pembelajaran yang menuntut tercapainya pengembangan keterampilan komunikatif antar siswa, yang mana dapat dicapai melalui model pembelajaran kooperatif teknik two stay two stray dalam pembelajaran IPS.

Kedua, pelaksanaan pembelajaran kooperatif teknik TSTS dalam pembelajaran IPS, dapat dikatakan sebagai pembelajaran yang menarik sekaligus sebagai upaya untuk mengembangkan keterampilan komunikatif antar siswa. Guru yang sekaligus berperan sebagai peneliti bersama-sama dengan siswa telah mengaplikasikan model pembelajaran kooperatif teknik TSTS dalam mengembangkan keterampilan komunikatif siswa dalam pembelajaran IPS. Berdasarkan hasil dari penelitian yang telah didapatkan, ternyata menghasilkan perubahan dalam hal kondisi belajar siswa yang mengacu pada pengembangan aspek kognitif, afektif, dan psikomotorik. Aktifitas siswa selama pembelajaran berlangsung, terlihat adanya kerjasama yang harmonis dan antar siswa. Dalam hal ini siswa merasa lebih mempunyai tanggung jawab perseorangan, mampu meningkatkan toleransi atau menghargai perbedaan karakter tiap siswa, dan mempererat hubungan persahabatan, serta melatih siswa dalam berkomunikasi dengan baik. Hasilnya, keterampilan komunikatif siswa mengalami perkembangan yang secara bertahap dari tindakan siklus I pertemuan 1 sampai siklus I pertemuan 2, dan peningkatan yang terlihat signifikan terjadi pada pelaksanaan tindakan siklus II pertemuan 1 dan pertemuan 2. Jadi berdasarkan dari seluruh tindakan yang telah dilakukan, dapat disimpulkan bahwa penerapan pembelajaran kooperatif teknik TSTS secara efektif dapat mengembangkan keterampilan komunikatif siswa kelas VIIIA SMPN 1 Cikoneng Kecamatan Cikoneng.

Ketiga, dalam merefleksi hasil dari penerapan pembelajaran kooperatif teknik TSTS dalam pembelajaran IPS, terdapat adanya kendala yang dialami oleh peneliti. Kendala yang dialami sebagian besar disebabkan adanya perbedaan karakter yang dimiliki oleh setiap siswa, sehingga membuat para siswa kesulitan dalam menjalin kerjasama yang lebih harmonis dengan siswa lainnya. Namun, kendala ini dapat diatasi melalui bimbingan, arahan dan diskusi yang dilakukan antara peneliti dan guru mitra. Selain itu, selama proses pembelajaran berlangsung, peneliti juga 
berupaya untuk selalu memberikan motivasi atau stimulus kepada siswa. Stimulus yang diberikan berupa nilai-nilai yang terkandung dalam pembelajaran kooperatif, dan pentingnya menerapkan keterampilan komunikatif dalam kehidupan siswa, sehingga perkembangan keterampilan komunikatif siswa dapat tercapai secara efektif dan maksimal.

Pada bagian ini, peneliti membuat saran bagi beberapa pihak yang terkait dengan penelitian. Berdasarkan pengalaman peneliti selama melaksanakan penelitian yaitu dengan menerapkan pembelajaran kooperatif teknik TSTS untuk mengambangkan keterampilan komunikatif siswa dalam pelajaran IPS adalah sebagai berikut:

Bagi Pihak Sekolah, peneliti berharap bahwa melalui penelitian ini dapat memberikan gambaran empiris tentang perkembangan keterampilan komunikatif antar siswa melalui pembelajaran kooperatif teknik TSTS. Sehingga sekolah dapat merekomendasikan kepada guru-guru untuk mencoba metode pembalajaran yang tidak hanya mementingkan segi pengetahuan, tetapi memperhatikan pula segi keterampilan siswa. Hal ini tentu bertujuan untuk tetap menjaga keharmonisan siswa dalam pergaulan di lingkungan sekolah, serta menghindari terjadinya konflik antar siswa yang dapat merugikan bagi pihak sekolah.

Bagi Guru, peneliti berharap dapat memberikan masukan kepada guru-guru dalam mengambangkan metode pembelajaran yang lebih bermakna, sehingga segala potensi keterampilan yang dimiliki oleh siswa dapat dikembangkan untuk mencapai tujuan pembelajaran secara optimal, karena peneliti menyadari bahwa guru tidak hanya sebagai sumber informasi, namun berperan juga sebagai fasilitator dan motivator bagi siswa dalam proses pembelajaran.

Bagi siswa, melalui penelitian ini diharapkan dapat memberikan manfaat yaitu mampu mengembangkan keterampilan komunikatif/bersahabat mereka melalui pembelajaran IPS, karena pada dasarnya, setiap siswa itu merupakan individu yang hidup dalam lingkungan sosial dan selalu membutuhkan hubungan kerjasama dengan individu lain. Jadi, harapan penuh yang dimiliki oleh peneliti, siswa-siswa diharapkan mampu memahami bahwa setiap manusia itu mempunyai karakter yang berbeda-beda, namun dari perbedaan tersebut bukan dijadikan suatu penghalang untuk menjalin hubungan yang lebih harmonis, baik dalam lingkungan sekolah, masyarakat maupun keluarga.

Bagi peneliti, penelitian ini dijadikan sebagai inspirasi dalam melakukan suatu kegiatan yang berguna di bidang pendidikan. Peneliti menyadari bahwa hasil penelitian ini bukanlah hasil penelitian yang sempurna. Jadi perlu adanya peningkata bagi peneliti selanjutnya agar memperoleh hasil penelitian yang lebih sempurna, terutama mengenai penerapan pembelajaran kooperatif teknik TSTS untuk mengambangkan keterampilan komunikatif siswa dalam pembelajaran IPS.

Demikian kesimpulan dan saran yang dapat penulis kemukakan. Semoga dapat berguna terhadap peningkatkan kualitas pendidikan di Indonesia dan secara khusus menjadi bahan pertimbangan guru-guru dalam menerapkan pembelajaran kooperatif teknik TSTS untuk mengembangkan keterampilan komunikatif siswa dalam pembelajaran IPS.

\section{Daftar Pustaka}

[1] Arikunto, S (2010). Prosedur Penelitian: Suatu Pendekatan Praktik. Jakarta: Rineka Cipta.

[2] Gunawan, R. (2011). Pendidikan IPS: Filosofi, Konsep dan Aplikasi. Bandung: Alfabeta. 
[3] Kemendiknas. (2010). Pengembangan Pendidikan Budaya dan Karakter Bangsa. Pusat Kurikulum-Badan Penelitian dan Pengembangan. Jakarta: Kementerian Pendidikan Nasional.

[4] Kesuma, et al. (2011). Pendidikan Karakter : Kajian Teori dan Praktek di Sekolah. Bandung: PT. Remaja Rosdakarya.

[5] Komalasari, K. (2011). Pembelajaran Kontekstual: Konsep dan Aplikasi. Bandung: Refika Aditama.

[6] Lie, A. (2008). Cooperative Learning. Jakarta: PT Grasindo.

[7] Munthe, B. (2009). Desain Pembelajaran. Yogyakarta: PT. Pustaka Insan Madani.

[8] Roestiyah. (2008). Strategi Belajar Mengajar. Jakarta: PT Rineka Cipta.

[9] Sanjaya, W. (2011). Penelitian Tindakan Kelas. Jakarta: Kencana Prenada Media Group.

[10] Sanjaya, W. (2011). Perencanaan dan Desain Sistem Pembelajaran. Jakarta: Kencana Prenada Media Group.

[11] Sapriya. (2009). Pendidikan IPS: konsep dan pembelajaran. Bandung: PT Remaja Rosdakarya.

[12] Sapriya, et al. (2008). Konsep Dasar IPS. Bandung: CV Yasindo Multi Aspek.

[13] Saptono. (2011). Dimensi-Dimensi Pendidikan Karakter: Wawasan, Strategi, dan Langkah Praktis. Jakarta: Erlangga.

[14] Sudjana, N dan Ibrahim. (2010). Penelitian dan Penilaian Pendidikan. Bandung: Sinar Baru Algesindo.

[15] Sugiyanto, (2010). Model-Model Pembelajaran Inovatif. Surakarta: Yuma Pustaka.

[16] Supardan, D. (2009). Pengantar Ilmu Sosial: Sebuah Kajian Pendekatan Striktural. Jakarta: Bumi Aksara.

[17] Suprijono, A. (2012). Cooperative Learning: Teori dan Aplikasi Paikem.

[18] Yogyakarta: Pustaka Pelajar.
[19] Trianto. (2010). Mendesain Model Pembelajaran Inovatif-Progresif. Jakarta: Kencana.

[20] Wahab, AA. (2009). Metode dan Model-Model Mengajar: Ilmu Pengetahuan Sosial. Bandung: CV Alfabeta.

[21] Wiriaatmadja, R. (2008). Metode Penelitian Tindakan Kelas. Bandung: PT Remaja Rosdakarya.

[22] Wiryanto. (2008). Pengantar Ilmu Komunikasi. Jakarta: Grasin 